\title{
unindra
}

Universitas Indraprasta PGRI

Address: Jl. Nangka No. 58 C (TB. Simatupang), Kel. Tanjung Barat, Kec. Jagakarsa, Jakarta Selatan 12530, Indonesia. +62 (021)

7818718 - 78835283; url: www.unindra.ac.id; cultural.syndrome@unindra.ac.id

\section{The Speech Acts of the Pangeuyeuks in the Ngeuyeuk Seureuh Ceremony}

Euis Kurniasih

Universitas Indraprasta PGRI

Correspondence regarding this article should be addressed to: Euis Kurniasih, euis99@gmail.com

Article History

Received : 31-05-2020

Revised : 04-07-2020

Accepted : 05-07-2020

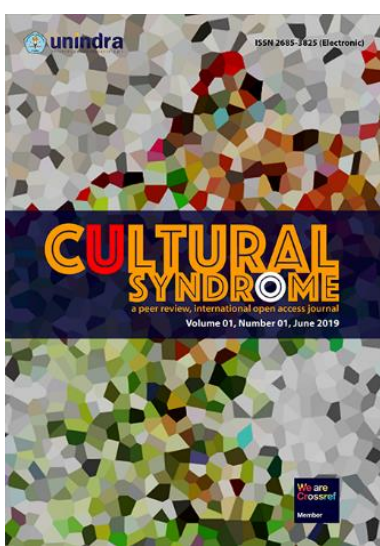

Cultural Syndrome

a peer review, internasional open access journal e-ISSN: 2685-3825

Editor: Saswati Bordolo

Publication details, including author guidlines https://journal.unindra.ac.id/index.php/cusy/ about/submissions\#authorGuidelines

\section{How to cite this article (MLA 8th)}

Kurniasih, Euis. "The Speech Acts of the Pangeuyeuks in the Ngeuyeuk Seureuh Ceremony". Cultural Syndrome, Vol.2, No.1, 2020, pp. 35-48., https://doi.org/10.30998/cs.v2i1.270

The readers can link to article via https://doi.org/10.30998/cs.v2i1.270

SCROLL DOWN TO READ THIS ARTICLE

Universitas Indraprasta PGRI (as Publisher) makes every effort to ensure the accuracy of all the information (the "Content") contained in the publications. However, we make no representations or warranties whatsoever as to the accuracy, completeness, or suitability for any purpose of the Content. Any opinions and views expressed in this publication are the opinions and views of the authors, and are not the views of or endorsed by Universitas Indraprasta PGRI. The accuracy of the Content should not be relied upon and should be independently verified with primary sources of information.

\section{(c) (i) 8}

This work is licensed under a Creative Commons Attribution-NonCommercial 4.0 International License.

Copyright by Euis Kurniasih (@ 2020)

The authors whose names are listed in this manuscript declared that they have NO affiliations with or involvement in any organization or entity with any financial interest (such as honoraria; educational grants; participation in speakers' bureaus; membership, employment, consultancies, stock ownership, or other equity interest; and expert testimony or patent-licensing arrangements), or non-financial interest (such as personal or professional relationships, affiliations, knowledge or beliefs) in the subject matter or materials discussed in this manuscript. This statement is signed by all the authors to indicate agreement that the all information in this article is true and correct 


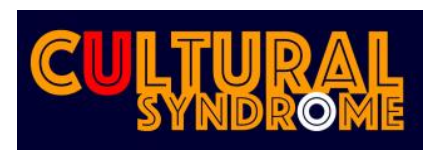

Vol.2, No.1, 2020, pp. 35-48

e-ISSN: 2685-3825

https://doi.org/10.30998/cs.v2i1.270

\title{
The Speech Acts of the Pangeuyeuks in the Ngeuyeuk Seureuh Ceremony
}

\author{
Euis Kurniasih \\ Universitas Indraprasta PGRI
}

\begin{abstract}
The Pangeuyeuks as guides in Ngeuyeuk Seureuh ceremony contains an important role to explain and embody the marriage values through symbols to any prospective bride and groom. This article describes the speech acts used by pangeuyeuks in Ngeuyeuk Seureuh ceremony. Descriptive qualitative and distributional methods were applied in doing the analysis of data. The speech acts were analyzed by the theory of illocutionary act to find the function of speech act, syntactic types of sentences to find the form of speech acts, and relationship between the function and form of speech acts to find the directness and indirectness of speech acts. The result shows that the illocutionary acts of pangeuyeuks classified into four types: assertives, directives, commissives and expressives, while the sytanctic types of sentences consist of declarative, interrogative, imperative and exclamatory. The direct speech acts are embodied in assertives, directives, commissives and expressives, wheareas the indirect speech acts are embodied in directive speech acts. The embodiment of the speech acts used by pangeuyeuks reflects special norms of interaction based on Sundanese local genius.
\end{abstract}

Keywords: speech acts, pangeuyeuks, Ngeuyeuk Seureuh, Sundanese, prewedding

Correspondence author: Euis Kurniasih, euis99@gmail.com, Jakarta, Indonesia

(c) (1) $(9$

This work is licensed under a CC-BY-NC

\section{Introduction}

The Sundanese society generally has rich traditions, including traditions before conducting the wedding ceremony. It is started from neundeun omong, narosan, ngalamar, seserahan, ngaras, siraman and ngeuyeuk seureuh. Due to the change of social dynamic on the society, not all the pre-wedding traditions are carried out in complete form. The Ngeuyeuk Seureuh is a pre-wedding ceremony that is often left behind. Only families who are quite wealthy or of those strongly upholding the custom that still undertaken this practice of the tradition, whereas the ceremony is one of the important processions to give teachings and advice to the prospective bride and groom about marriage values. 
The Ngeuyeuk is derived from the word 'heuyeuk' which means regulating, arranging or working on (Rachmawaty). Ngaheuyek nagara means regulating a country. Ngeuyeuk pare means working in the field to separate the grains of rice from the stem. Then, paheuyeuk heuyeuk leungeun can be said as holding hands together or co-operating each other. Therefore, ngeuyeuk seureuh literally means arranging betel and metaphorically means working on something together.

Ngeuyeuk seureuh is held on the night before the wedding day. It is attended by the elders, relatives of prospective bride and groom as well as adult guests. The bride and groom sit before material and tools in the center of the room called paramodana. The material and tools are the symbols utilized by pangeuyeuk, the leader of the ceremony, to explain marriage values that become the guide for their marriage life. The symbols which come from nature and traditional household tools show the ability of Sundanese ancestors to look at nature and live in harmony so their behaviors are filled with ethics and morals passed on next generation (Rusnandar).

The topic of ngeuyeuk seureuh ceremony has been investigated by some researchers. Those research aims are to describe the speech style used in ngeuyeuk seureuh ceremony which consists of frozen, formal and intimate(Kurniasih "Ragam Bahasa Dalam Upacara Pra-Nikah Adat Sunda "Ngeyeuk Seureuh""), to holistically draws the component communication in Ngeuyeuk Seureuh by ethnography of communication theory (Kurniasih "Peragaan Simbol Dalam Upacara Ngeuyeuk Seureuh (Kajian Etnografi Komunikasi)"), to reveal the sequences of Ngeuyeuk Seureuh procession and meaning of the symbol (Rusnandar; Suherlan). This research will be more focused on speech acts used by pangeuyeuk in organizing ngeuyeuk seureuh ceremony.

Ngeuyeuk aeureuh is a speech event in Sundanese speech community which needs a speech competence for the speaker. Pangeuyeuk as the speaker has to fill some of criteria such as already getting married, having enough experience and knowledge, considered as elders in the community, having the public speaking ability which specifically can apply proper Sundanese speech style ethics and can elaborate the meaning of the symbols (Kurniasih "Peragaan Simbol Dalam Upacara Ngeuyeuk Seureuh (Kajian Etnografi Komunikasi)"). Based on the fact that Ngeuyeuk Seureuh is getting rare to be conducted and the special criteria for pangeuyeuk, research on speech acts of pangeuyeuk becomes necessary as a form of language documentation and as the reference for the community who wants to revitalize this tradition.

In a speech event, a speaker does not only produce utterances in the form of words or sentences but the speaker actually takes actions through the utterances. Actions taken through utterance are called as speech acts ( $\underline{\text { Yule })}$. Speech acts are divided into three types, namely locutionary acts, illocutionary acts, and perlocutionary acts. The locutionary act is the act of uttering a meaningful linguistic expression. Illocutionary act is a speech act that contains communicative power functions to achieve various communication objectives such as making statements, making promises, making offers and others. Perlocutionary acts are the effects or actions of the listener which caused by the utterances produced. This research focuses on the illocutionary acts. 
Searl elaborates five basic categories of illocutionary acts: assertives, directives, commissives, expressives, and declarations. These five basic categories refer to general functions of speech acts ( $\underline{\text { Yule }})$. Each illocutionary act shows points of utterances: the assertives consist of representing as actual a state of affairs, the directives consists of making an attempt to get the hearer to do something, the commissives consist of committing the speaker to a future course of action, the expressives consist of expressing propositional attitudes of the speaker about a state of affairs, and the declarations consist of performing an actions which bring into the existence state of affairs by representing oneself as performing that action (Vanderveken). The point of utterances in illocutionary acts can be determined by illocutionary force indicating device which consists of performative verb, word order, stress and intonation (Yule).

Speech acts are also analyzed by syntactic types of sentences such as declarative, conditional, imperative, interrogative and exclamatory sentences (Vanderveken). Yule states that the sentence types and the function of speech acts have relationship both direct and indirect. If the sentence structure is in line with the function, like declarative sentence is used to make statement, it shows direct relationship or called as direct speech acts. In the other side, if the sentence structure is not in line with the function, like declarative sentence is used to make a request, it shows indirect relationship or called as indirect speech acts.

The analysis of these speech acts are useful to illustrate the kinds of things one can do with words and to identify some of conventional utterance forms that one can use to perform specific action ( $\underline{\text { Yule }})$. Therefore, the central aim of this paper is to describe the function, form and relation between function and form of speech acts used by pangeuyeuks in Ngeuyeuk Seureuh ceremony.

\section{Methods}

This research applies descriptive qualitative method. Qualitative method is a procedure which produces written and spoken data in a speech community, while descriptive method aims to make a description of data which are systematic, factual and accurate (Djadjasudarma). The data of this research is the utterancess of pangeuyeuks in the Ngeuyeuk Seureuh ceremony conducted by a Sundanese traditional community in Kuningan West Java. In Ngeuyeuk Seureuh ceremony, pangeuyeuks guide prospective bride and groom (for next it is abreviated as PBG) to demonstrate a number of symbols. The researcher only focuses on seven demonstration of symbols such as the simsim sumbu tujuh (oil light with seven wicks), the turub mandepun (white cloth which covers all symbols), betel, the alu-lumpang, areca nut flower, areca nuts, and coin money. The pangeuyeuks who guide demonstration of the seven symbols refer to two elders coded as $\mathrm{P} 1$ and $\mathrm{P} 2$.

Considering that this research is the continuation of the researcher's previous research, so the researcher utilized the transcription file of the Ngeuyeuk Seureuh ceremony that she has then focused to analyze the utterances produced by P1 and P2. 
Then, distibutional method is used as the method of data analysis. Distributional method uses determining tool in the language itself and the technique of sorting data based on the category of its grammatical elements in accordance to natural characteristics which belongs to the research data (Djadjasudarma). To find the function of speech acts, the data is classified into types of illocutionary acts (Searle), to find the structure form of sentence in the speech acts, the data is classified into syntactic types of sentences (Vanderveken), and to find the relation between the function and the form of speech act, the data is classified into direct and indirect speech act ( $\underline{\text { Yule }})$.

\section{Result and Discussion}

The pangeuyeuks utterances which guide the seven demonstrations of symbols in Ngeuyeuk Seureuh are classified into four types, such as assertives, directives, commissives, and expressives, whereas the form of sentence types of the speech acts are declarative, interrogative, imperative and exclamatory, as presented in the table below.

Table 1 Form and General Function of Speech Acts Frequency

\begin{tabular}{llllll}
\hline No & Speech Act & Declarative & Interrogative & Imperative & Exclamatory \\
\hline 1. & Assertives & 35 & - & - & - \\
2. & Directives & 14 & 12 & 59 & - \\
3. & Commissives & 1 & - & - & - \\
4. & Expressives & - & - & - & 7 \\
\hline & Total & 50 & 12 & 59 & 7 \\
\hline
\end{tabular}

As seen from the tables, the types of functions and sentences of speech act which most frequently appeared are directives speech acts in the form of imperative sentences. Next, the relationship between the function and form of speech acts shows the direct speech act is the most applied by the pangeuyeuks in the Ngeuyeuk Seureuh ceremony as displayed on the table below:

Table 2 Direct and Indirect Speech Acts Frequency

\begin{tabular}{llll}
\hline No & Speech Act & $\begin{array}{l}\text { Direct } \\
\text { Speech }\end{array}$ & Indirect Speech \\
\hline 1. & Assertives & 35 & - \\
2. & Directives & 70 & 15 \\
3. & Commissives & 1 & - \\
4. & Expressives & 7 & - \\
\hline & Total & 113 & 15 \\
\hline
\end{tabular}

\section{Assertive Speech Acts}

Pangeuyeuks produce the assertive speech acts in the form of declarative sentences indicating several functions, namely showing the presence of symbols, explaining the 
symbols characteristics, its function and meaning, as well as responding to what PBG has done.

Speech acts that function to show the presence of symbols are found in the demonstration of the simsim sumbu tujuh, turub mandepun, alu-lumpang, areca nut flower and areca nut. P1 and P2 express the utterance before they give instructions to PBG to conduct the demonstration. Here is an example of the speech data:

1. Hidep anaking, dipayuneun hidep aya simsimsumbu tujuh".

You my children, in front of you there simsim sumbu tujuh

"My children, in front of you there is an oil lamp with seven wicks." (1.1)

Pangeuyeuk's speech above is the utterance contained in the demonstration of oil lamp with seven wicks. The speech form is a declarative sentence containing two adverbs di payuneun hidep 'in front of you' and aya 'there'. From the adverbs, we can see that the function of speech is to show the existence of oil lamp with seven wicks placed is in front of the PBG.

Speech acts that serve to explain the characteristics of the symbol found in the demonstration of betel and flower of areca nut. Explanation of the characteristics of betel is presented before P1 gives instructions to the PBG to put together two betel leaves, while the explanation of characteristics of areca nut flower is presented after PBG performs instructions from P2 to remove the flower from the lid. Explanation of the characteristics of the symbol aims to provide a more detailed understanding so that the PBG is able to understand the meaning contained in each symbol display. Here is an example of speech, for example, in a traditional betel demonstration.

2. Ari seureuh hiji tutuwuhan anu henteu laas $k u$ wanci,
partikel betel one plantation which not die by time

dina halodo usum, dina ngijih oge janten; tonggoy

in dry season, in wet also grow, strong

"Betel is a plantation which resist to all weather both dry and wet season.." (3.7)

P1 expresses the expression above in the form of declarative sentence. It explains that the betel is a plant that is able to live and to survive in all seasons. These characteristics serve as teachings that when PBG has lived a domestic life, it should be strong in any situation.

Speech acts that function to explain the meaning of symbols are contained in the oil lamp with seven wicks demonstration. P1 expresses this utterance when PBG had finished igniting the oil lamp with seven wicks as follows:

3. silokana simsimsumbu tujuh aya dinten anu tujuh the symbol oil lamp with seven wicks there days which seven 


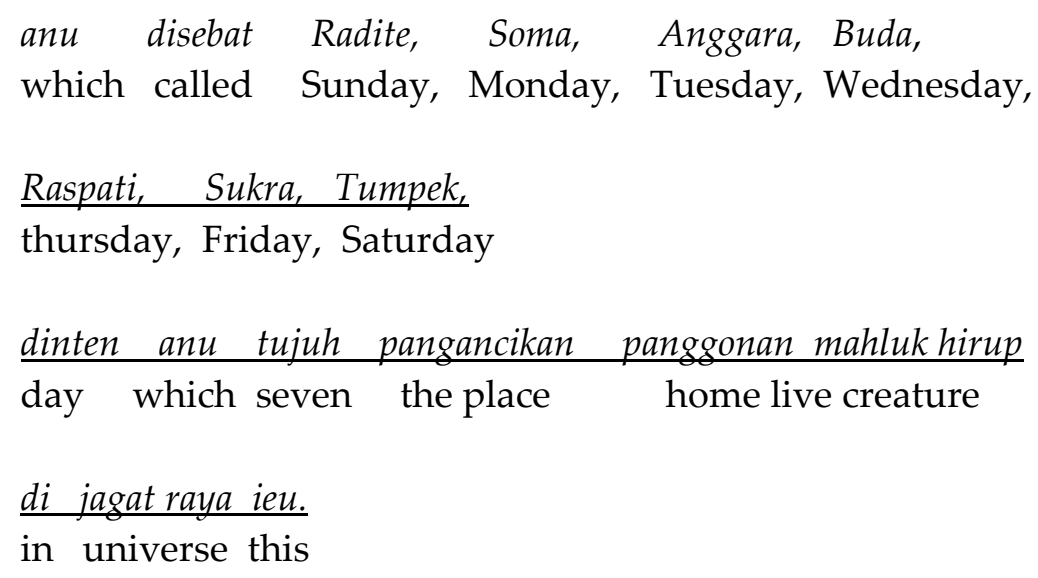

“The oil lamp with seven wicks symbolizes seven days in a week, Sunday, Monday, Tuesday, Wednesday, Thursday, Friday, Saturday. The seven days as the time and place of live creatures in this universe" (1.8)

The form of speech above is a declarative sentence which contains of the explanation of the symbolic meaning of the oil lamp with seven wicks. The number of seven refers to the seven days; Sunday, Monday, Tuesday, Wednesday, Thursday, Friday and Saturday. The day names in the speech use Sanskrit namely Radite, Soma, Anggara, Buda, Respati, Sukra and Tumpek. The seven days are symbolized as panggonan 'place of residence', meaning that people live their lives on this earth through the seven days. In term of the relationship of the function and form of speech act, it can be seen that all function of assertive speech acts which are to show, to explain and to respond are in the form of declarative sentence. It means that pangeuyeuks express directive speech acts in all assertive functions.

\section{Directive Speech Acts}

The directive speech acts are the most dominant speech acts types in Ngeuyeuk Seureuh. These directive speech acts show nine functions (1) giving instructions, (2) correcting, (3) prohibiting, (4) warning, (5) inviting, (6) questioning (7) advising, (8) recommending and (9) allowing. They are expressed in several forms of sentences namely imperative, interrogative and declarative as follows.

Speech acts that function to give instructions are in all symbols, because through these speech acts, P1 and P2 can make PBG perform symbol. The instructions given are vary depending on the symbols displayed. The following are examples of giving instructions taken from the demonstration of making a lungkun, betel leaf which is rolled and tied with yarn.

1. Cobi ayeuna $k u$ hidep cepeng duanana ieu seureuh teh, try now by you hold both this betel particle

kedah pabeuteung-beuteung

must stomach with stomach 
paadu beuteung, diadukeun!

stomach, united!

"Now, the both betel leaves are hold and united the stomach with the stomach!" (3.12)

2. Saparantosnakitu, ayeuna $k u$ hidep

After that, now by you

digulungkeun ti sisika tengah!

Rolled from the side to the center!

"After that, rolled the betel leaves from the side to the center!" (3.15)

3. Saatos ngagulung kieu, mangga ditalian!

after rolled like this please bound

“After rolled, bound it!" (3.23)

The three speech acts above are expressed in imperative sentence forms containing imperative verbs and subtle imperative markers. Sample 1 has three imperative verbs such as cepeng 'hold', kedah 'must', and diadukeun 'put together' and one imperative marker in high speech level, cobi 'try'. The word cepeng 'hold' is an imperative verb while the word kedah 'must' is a modality verb that indicates a necessity. Then, the word cobi 'try' is an imperative marker in Sundanese. In the context of the speech in sample 1, P1 instructs PBG to hold and to unite the two betel leaves in the position of the betel leaf facing each other. Sample 2 consists of one imperative verb in the form of a passive digulungkeun 'be rolled' which has a prefix construction di- and a suffix -keun. In the context of the speech act, P1 instructs PBG to roll two betel leaves that had been put together from the side to the center. Sample 3 has a passive imperative verb that is ditalian 'be bound' which contains the prefix $d i$ - and suffix -an and one imperative marker that is mangga which means 'please'. In the context of speech act, P1 instructs PBG to tie betel leaves which had been rolled with yarn. Passive form and imperative markers in the instruction are related to Sundanese etiquette which is a form of politeness to ask people to do something. Thus, from the three speech acts, it can be seen that the steps to make lungkun consist of uniting two betel leaves, rolling the betel leaves together and binding the betel leaves that have been rolled with yarn. The three speech acts of giving instructions were responded by PBG by doing what was instructed in accordance with what was intended by P1.

Speech acts that function to prohibit are speech acts that instruct or advise PBG not to do something. This speech act was expressed by both P1 and P2 in all symbol demonstrations both in the section giving instructions and giving advice. Here are some examples: 
4. Ké ulah waka dibuka, kéheula!

Wait a minute don't firstly be opened, wait a minute!

“Just wait a minute, don't open first!" (7.5)

The speech act above was expressed by P1 in the demonstration of looking for coin money, when PBG were instructed to get ready. At that time, PBG seemed to be impatient to hunt for coins so that the mat would almost be opened first before they were alowed. P1 forbids them from opening the mat first because P1 will give the signal first. The prohibition functions are expressed by $\mathrm{P} 1$ in the form of imperative sentences which contain prohibition marker and passive imperative verb. The word ulah 'don' $t$ ' which states the prohibition and the word dibuka 'be opened' is a passive imperative verb. Thus, the two words function to forbid PBG to open the mat first.

Then the sample of direct speech acts of prohibiting in giving of advice are presented in the following:

5. ...mung kadé anaking ulah kawas élmu ajug,

however beware my children don't like oil lamp

ari $\quad k a$ batur tiasa masihan caang narawangan

if to others can give light brightly

tapi diri hidep masih keneh kapoékan,

but yourself still in darkness

apansaur sepuh oge sebatkeun caangna sing nawarangan

like said parents too stated the light be bright

“... but beware my children do not be like the oil lamp, you can give a bright light to others but you are still in the darkness, as stated by parents give a bright light." (1.10)

The directive speech above is said by P1 when giving advice through an explanation of the oil lamp with seven wicks symbolic meaning. The utterances are expressed in the form of declarative sentences containing prohibited speech acts. This is indicated by the use of the clause 'mung kade anaking ulah kawas elmu ajug'. The word 'kadé' which means 'be careful' indicates a warning and the word 'ulah' denotes a prohibition. The warnings and prohibitions are manifested in the form of parable expressions, namely the knowledge expert also "like the knowledge of oil lamp" which refers to the behavior of people who are only able to advise others while themselves still need to be advised. This phrase contained advice that we must introspect ourselves by correcting our own behavior. After expressing advice that contains commands and prohibitions, the next advice contained is indicated by the clause caangna sing narawangan 'the light should be bright'. The word narawangan 'transparent' implies translucent meaning or visible clearly and visibly outside and inside, so that the 
intention to convey is the light or knowledge that we have and we share must be useful and be actualized both for ourselves and others.

The advice expressed in the clause 'mung kade anaking ulah kawas elmu ajug' is a form of proverb. In the Sundanese society, using proverb is a part of communication ethics to educate others in all aspects of life because Sundanese people prefer giving advice subtly without making others be offended (Sutisna). That is why the directive speech acts expressed in indirect speech has advising function.

The directive speech acts which function to give warning are in demonstration of simsim sumbu tujuh, betel, areca nut and coin money. For the sample, the speech act is taken from the demonstration of taking coin money as follows:

6. Awas ké heula, dietang dugikeun ka tilu nya!

"Be ready, it will counted from one to three!"

The directive speech above is expressed in imperative sentence shown by verb 'awas' in the beginning of the sentence. The verb functions to warn PBG before taking coin money.

The directive speech functions to invite only contained in betel demonstration. P1 invites audiences to join in chewing betel as follows:
7. Bilih
sepuh
aya
nu badenyarengan?
Maybe
the elders
there which will accompany

“is there elders who will accompany?"(3.32)

The speech act above is an interrogative form which is indicated from the intonation used by P1. Although the form is interrogative sentence, but it functions as invitation for the guest who attend the ceremony.

The directive speech acts which function to quest contain in some symbolic demonstration of betel, areca nut flower, areca nuts and coin money. The following is the example of questioning function in betel demonstration:

\section{Kumaha katingalna, Cep? beureum teu?}

How it looks, Cep? red not?

"How does it look, Cep? Is it red?" (3.42)

The speech act above is expressed by P1 in the form of interrogative sentence, after PBG spit the betel that has been chewed. He asked with question word kumaha 'how' and yes no question to ask whether the betel becomes red or not. 
The directive speech acts which function to advise contains in all symbol demonstration. It is because the purpose of the ceremony is to give marriage advice through symbols. Here is the example:

9. Caangna minangka sang surya,

The light like a sun

silokana kanggo hidep dina laki rabi
the symbolic meaning for you in husband-wife

kedah silih caangan antawis carogé sareng garwa must each other give light between husband and wife

pon kitu deuigarwa sareng carogé.

so that again wife and husband

"The light is like a sun, in the marriage life between husband and wife must give light each other." (1.9)

The speech act above is in the demonstration of simsim sumbu tujuh. P1 expresses this speech act after PBG light the seven wicks of oil lamp. The sentence structure is in the form of declarative which consist of two clauses. The first clause caangna minangka sang surya 'the light is like a sun' is a parable of the oil lamp light symbolize as a sun. The second clause is 'silokana kanggo hidep dina laki rabi kedah silih caangan antawis carogé sareng garwa kitu deui garwa sareng carogé'. Advising function in the clause is indicated by the verb phrase kedah silih caangan 'must give the light each other'. The light in that context means kindness. As husband and wife, they must love and help each other.

The directive speech act which function to recommend is in the following:

10. Saur ibu mah saur kasepuhan mah

said mother -partikel- said elders -partikel-

saé__ disimpen di padaringan, ku hidep duaan.

good be stored in rice storage by you two

"Mother and elders said that it is better for you to keep it in rice storage." (7.26)

The speech act above is in the form of declarative sentence. By that speech act, P1 recommend PBG to keep coin money that they get in rice storage. The recommendation is shown by the clause 'saé disimpen di padaringan' The word 'saé' in the clause means 'better'. Then, the word 'disimpen' is a passive imperative verb. The recommendation is just the suggestion which does not have to be done.

The directive speech acts that function to allow is expressed by P2 after finishing to guide alu-lumpang, areca nuts flower and areca nuts demonstration as follows: 


\section{Mangga lajengkeun ka pangjejer!}

Please continue to master of ceremony

"Please continue by the master of ceremony." (6.9)

The speech act above is expressed in the form of imperative sentence. It is indicated by the active imperative verb lajengkeun 'continue' dan the high level speech marker 'mangga' which equivalent with 'please'. The speech act is intended to allow P1 to continue other demonstration symbol.

Concerning on the relationship between the function and form in directive speech acts, it reveals some variations. The function of giving instruction, correcting, prohibiting, warning and allowing are in the form of imperative sentences so they are categorized as direct speech acts. The function of questioning that is in the form of interrogative sentence is categorized as direct speech acts too. Then, the function of advising in the form of declarative sentence and inviting in the form of interrogative sentence are categorized as indirect speech.

\section{Commissive Speech Acts}

Commissives are speech acts that contain the speaker's intention for doing something in the future. The commissive speech acts are only expressed by P1 in the coin money demonstration as follows:

1. Badé dikomando heula..

will be commanded first.

"I will give a cue first." (7.7)

P1 expresses the commissive speech act above in the form of declarative sentence, after giving a warning to PBG not to open the mat before the cue. The form of declarative sentence contains adverb modality bade 'will' and passive verb dikomando 'be commanded'. Adverb modality bade 'will' denotes something that will be done by the speaker while the passive verb 'commanded' indicates the activity that will be done by the speaker. Thus, the function of the speech is that P1 intends to give a cue to PBG before they take the coins money behind the mat. The relationship of function and form in commissive speech acts shows the direct speech acts because the function of committing is embodied in the form of declarative sentence.

\section{Expressive Speech Acts}

Expressive speech acts describes the feelings of the speaker. In the Ngeuyeuk Seureuh ceremony, expressive speech acts are stated by P1 in several symbol demonstration like chewing betel and taking coin money. Expressive speech acts are expressed in the form of exclamative sentences consisting of several functions: expressing response, giving thanks, and expressing wonder. 
Expressive speech acts to express evaluative responses are found in all symbol displays. The response in question is the response of $\mathrm{P} 1$ to the demonstration by the bride and groom in rolling turub mandepun (white cloth which covers the symbols). Here is an example of the speech:

1. Tah kitu!

Yeah, that's

“Yeah that's right!" (2.5)

Speech act above is said in rolling turub mandepun demonstration. The utterance in this data was stated by P1 after warning PBG not to roll turub mandepun in hurry. Therefore, after PBG rolled it slowly as instructed, then P1 stated the response that the demonstration they had done was correct. The utterances are in the form of exclamative sentences which contain exclamation term ' $t a h^{\prime}$ and demonstrative pronoun ' $k i t u$ '. The exclamation word 'tah kitu' functions to evaluate that what PBG performed is correctly as what is instructed.

Expressive speech acts function to thank is expressed by P1 in the turub mandepun demonstration. The thanking expression said when PBG finished to roll turub mandepun as stated below:

2. Hatur nuhun.

Give thanks

“Thank you!” (2.15)

Expressive speech act that functions to express wondering is in the betel demonstration. P1 uttered the expression of wonder, when he saw the bride looked confused while chewing the betel as follows:

3. Duh nengsusi mah mani culangcileung kitu geuning!he.he.

Ouch, nèng Susi partikel looked confused so exclamatory word.he..he..

“Ouch you looked so confused!"..he..he.. (3.38)

Speech act above is in the form of exclamative sentences containing several exclamation words such as 'duh' and 'geuning'. The exclamation words ' $d u h$ ' and 'geuning' in the context of the speech function shows wondering. That expression is accompanied by a joke which is marked by paralinguistic acts of laughter. The relationship of function and form in expressive speech acts shows the direct speech acts because the function of responding and thanking are embodied in the form of declarative sentence. A joke is a form of humor. It functions to maintain the continuity of communication and to make the atmosphere livelier. However, the humor delivery in Sundanese traditional ceremony does not cause offense, because the ceremony are important, private and sacred (Nurfarida and Tustiantina). In other words, a joke 
expressed with the ethics is acceptable and become the custom in the ngeuyeuk seureuh ceremony.

\section{Conclusion}

In the Ngeuyeuk Seureuh ceremony, the pangeuyeuks express assertives, directives, commissives and expressives in the four types of sentence structures: declarative, interrogative, imperative and exclamatory sentences. The assertives which function to show, to state and to explain, are expressed in direct speech acts. The directives which function to instruct, to correct, to warn, to invite, to question, and to allow, are expressed in direct speech acts, while the directives which function to advise and to recommend, are expressed in the indirect speech acts. Next, the commissives which function to commit and the expressive which function to respond and to thank are expressed in the direct speech. The directives as the dominant speech acts with the most variation of syntactic types of sentence reflecting the main acts in the Ngeuyeuk Seureuh to demonstrate the symbolic meaning and to explain the meaning of the symbol as the media for transferring advices and teachings about the marriage life to the prospective bridge and groom. The assertives, commissives and expressives which reveal as the supported acts give the picture of dynamicity of the ceremony. Ngeuyeuk Seureuh as the informal family education domain is still can be investigated deeper on some other theories of languages such as metaphor and linguistics cognitive. Besides, the music and lyrics which open, and accompany the demonstration of symbols and which are close to the Ngeuyeuk Seureuh ceremony can also be analyzed.

\section{References}

Djadjasudarma, T Fatimah. Metode Linguistik: Ancangan Metode Penelitian Dan Kajian. PT. Refika Aditama, 2010.

Kurniasih, Euis. "Peragaan Simbol Dalam Upacara Ngeuyeuk Seureuh (Kajian Etnografi Komunikasi)." vol. Masters, Thesis, Universitas Diponegoro, 2013. general editor, Ph.D Drs. J Herudjati Purwoko, http://eprints.undip.ac.id/48481/http://eprints.undip.ac.id/48481/.

---. "Ragam Bahasa Dalam Upacara Pra-Nikah Adat Sunda “Ngeyeuk Seureuh"." International Seminar Language Maintenance and Shift II, edited by Agus Subyanto et al., Universitas Diponegoro and Balai Bahasa Jawa Tengah, July 5-6 2012, pp. 411-415. http://eprints.undip.ac.id/54059/http://eprints.undip.ac.id/54059/.

Nurfarida, Lela and Diana Tustiantina. "Deskripsi Wacana Humor Dalam Upacara Adat Pernikahan Sebagai Wujud Pelestarian Tradisi Lisan Di Masyarakat." Jurnal 
Membaca Bahasa dan Sastra Indonesia, vol. 2, no. 2, 2017, pp. 127-138, http://jurnal.untirta.ac.id/index.php/jurnalmembaca/article/view/2707.

Rachmawaty, Enden Irma. "Makna Dan Simbol Dalam Upacara Adat Perkawinan Sunda Di Kabupaten Bandung." Patanjala : Jurnal Penelitian Sejarah dan Budaya, vol. 3, no. 2, 2011, pp. 245-259, doi:http://dx.doi.org/10.30959/patanjala.v3i2.277.

Rusnandar, Nandang. "Pranata Pendidikan Pada Upacara Ngeuyeuk Seureuh, Upacara Masa Kehamilan, Dan Ngasuh Budak." Patanjala : Jurnal Penelitian Sejarah dan Budaya, vol. 9, no. 1, 2017, pp. 31-44, doi:http://dx.doi.org/10.30959/patanjala.v9i1.344.

Searle, John R. Expression and Meaning: Studies in the Theory of Speech Acts. 1 edition, Cambridge University Press, 1979.

Suherlan, Cece. "Ulikan Sémiotik Dina Upacara Adat Ngeuyeuk Seureuh Di Désa Légok Kalér Kecamatan Paseh Kabupaten Sumedang." Program Studi Pendidikan Bahasa Daerah, vol. Sarjana (S1), Skripsi, Universitas Pendidikan Indonesia, 2014. http://repository.upi.edu/15594/http://repository.upi.edu/15594/.

Sutisna, Ade. "Aspek Tatakrama Masyarakat Sunda Dalam Babasan Dan Paribasa." Lokabahasa: Jurnal Kajian Bahasa, Sastra dan Budaya Daerah serta Pengajarannya, vol. 6, no. 1, 2015, pp. 1-10, doi:https://doi.org/10.17509/jlb.v6i1.3137.

Vanderveken, Daniel. Meaning and Speech Acts, Volume I: Principles of Language Use. 1 edition, vol. 1, Cambridge University Press, 1990.

Yule, George. Pragmatics. OUP Oxford, 1996. H G Widdowson. 